\begin{tabular}{|c|c|}
\hline 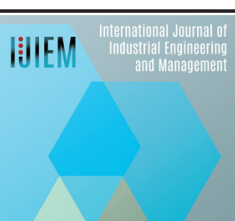 & $\begin{array}{l}\text { journal homepage: } h \text { ttp://ijiemjournal.uns.ac.rs/ } \\
\text { International Journal of Industrial } \\
\text { Engineering and Management }\end{array}$ \\
\hline 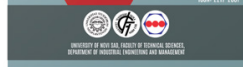 & Volume 11 / No 1 / March 2020 / 61 - 70 \\
\hline
\end{tabular}

Review article

\title{
Product-service systems benefits and barriers: an overview of literature review papers
}

\author{
S.R. Moro ${ }^{\text {a* }}$, P. A. Cauchick-Miguel ${ }^{\text {a,b }}$, G.H.S. Mendes ${ }^{c}$ \\ a Federal University of Santa Catarina, Post-graduate Program in Production Engineering, Florianópolis, SC, Brazil; \\ $b^{b}$ Federal University of Santa Catarina, Production and System Engineering Department, Florianópolis, SC, Brazil; \\ ${ }^{c}$ Federal University of São Carlos, Production Engineering Department, São Carlos, SP, Brazil
}

A B STRACT

Product-Service Systems (PSS) appears as an emergent subject, gaining the attention of many researchers, and an increasing interest of organizations. As many literature reviews have been conducted in PSS-related field, this paper aims to overview publications from 2006 to 2018 by highlighting PSS benefits and barriers. Content analysis was used to codify data collected in the publications. The main characteristics of the literature reviews are provided as well as a set of 36 PSS benefits and 24 barriers organized in categories and sub-categories. Analyzing PSS-related review papers allows identifying future research opportunities which can foster the design and implementation of PSS business models.

\section{Introduction}

Product-Service Systems (PSS) were proposed by the United Nations Environment Program (UNEP) in the late 1990s. Publications on the subject began to emerge after the release of the report "Product Service systems, Ecological and Economic Basics" [1], which was written to stimulate discussion on the subject, being commissioned by the Dutch Ministries of Environment and Economic Affairs. PSS is offered as an integrated package of products and services $[2,3]$ with the aim to deliver an outcome, functionality, or a system's availability [4]. While providing solutions that can meet the needs of end customers,
ARTICLE INFO

Article history:

Received October 11, 2019

Revised February 20, 2020

Accepted February 21, 2020

Published online March 4, 2020

Keywords:

Integrated product-service;

Literature review;

Product-service system;

PSS business model

*Corresponding author:

Suzana R. Moro

suzana.moro19@gmail.com 
tion, PSS has incorporated digital elements. Consequently, different types of digital-driven PSS are presented such as digitalized PSS [10], digital servitization [11], and smart PSS [12,13]. Moreover, trends such as cloud computing, internet of things (IoT), and predictive analytics are acting as facilitators towards service inclusion in manufacturing firms' business models [14]. Digitalized PSS incorporates information and communication technology to provide a complex PSS, delivering maximum availability, optimizing processes, and resource use [10]. In the same way, smart PSS use information technology, integrate various stakeholders through value co-creation, and are provided by intelligent systems [13].

Considering that PSS appears as an emergent subject, a number of literature reviews publications about it have been developed in recent years by authors from different areas. Some of these PSS literature reviews made comparisons against the previous ones showing the differences between other literature reviews or examining the applied methods, the number of articles analyzed, and time range (e.g., refs. $[5,15])$. Comparing the contributions of these literature reviews could be useful for researchers that wish to get a quick overview of PSS characteristics [15].

By analyzing the literature reviews, it is possible to perceive the research progress on a subject, the historical development of the studies, and classify the process to discover possible directions for future research [16]. When analyzing the literature reviews, one obtains the vision of research groups in the subject, involving in a second level (publications cited) a large number of publications reviewed. In fact, some of the purposes of the literature review are justified in the analysis of reviews, such as [17]: identifying new ways of interpreting and clarifying the gaps of the previous research, identifying what was covered by previ- ous revisions to avoid duplicate efforts and place the work that will be done within existing literature. In addition, a comparison of the results obtained allows a better understanding of how the literature reviews were carried out, identifying trends within the literature to date [16].

In this sense, this paper aims to provide an overview of PSS literature reviews, emphasizing PSS benefits and barriers pointed out by these reviews seeking to guide researchers on where to find the information needed for their studies. Future PSS research opportunities were also suggested before conclusion section.

\section{Research Methods}

An overview of review articles was conducted based on the recommendations of Ballard and Montgomery [18], in order to compare and contrast literature reviews publications on PSS. This kind of review consists of following a guideline to systematically search for, select, and then analyze and synthesize research evidence [19]. In this paper, a literature analysis was conducted to provide an overview, that aims at surveying the literature and describe its characteristics [19].

\subsection{Data searching and selection}

Procedures for data searching and selection were inspired in several works (e.g. refs. [3,20,21]). The search was conducted in three relevant databases (Scopus, ISI Web of Science, and Science Direct), in December 2017. Figure 1 depicts the visualization of articles search and selection steps as well as the resulting number of articles after each step (based on ref.

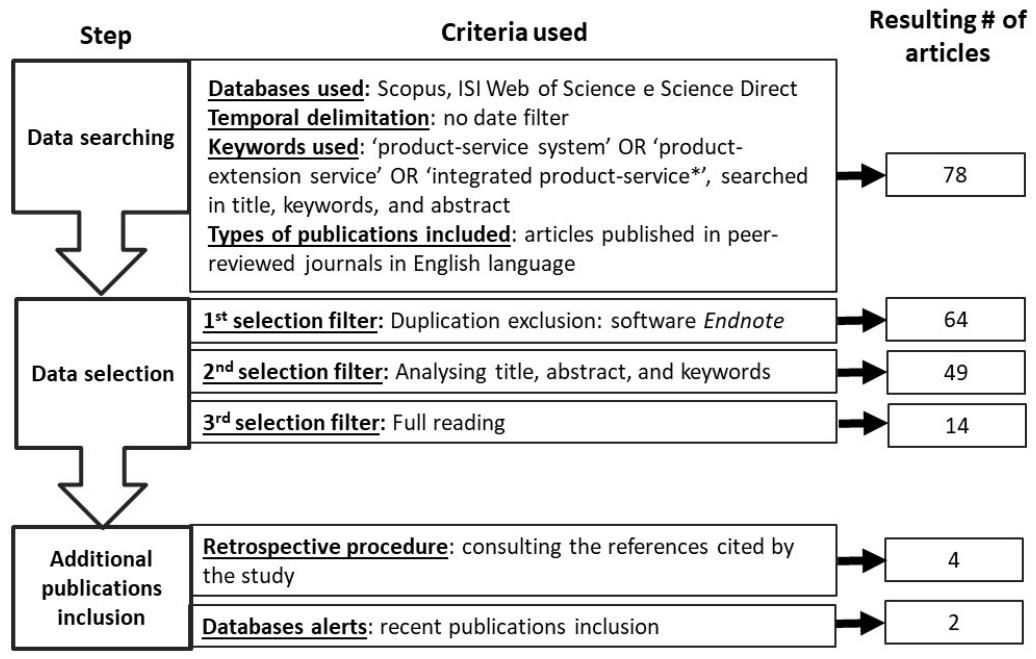

Figure 1. Data searching and selection procedures adopted (constructed by the authors with support of ref. [21]) 
[21]. Only review articles published in peer-reviewed journals in English language were selected, resulting in 78 publications. Articles were firstly selected by duplication exclusion, remaining 64 . Then, through the reading of the title, keywords, and abstract, 49 publications remained.

Afterwards, the alignment of the publications with the PSS subject was verified and, finally, the remainder was read in full. Fourteen reviews were selected. The selected publications after the third selection filter were the ones that literature review represents the core of the publication and in which the keywords used for the search were related to the PSS subject, or if they were not evident in the text if the objectives of the literature review paper were related to PSS.

The retrospective procedure [17] was applied to ensure that important publications were not missed. This procedure consists of consulting the references cited by the study as recommended elsewhere [22]. The references of the 14 selected publications were checked: first, it was verified whether the publication was a literature review, then title, keywords, and abstracts were read, and subsequently reading in full was conducted - resulting in the inclusion of four additional publications. The retrospective procedure was particularly important because the first literature reviews in PSS were not coined with the term 'literature review', and also ensured the inclusion of studies that are not indexed in the three databases consulted.

Alerts were settled in the databases to be notified about recent publications inclusions to provide the temporal updating of the research. Two publications of 2018 were included using this procedure. The final selected portfolio of articles analyzed consists of twenty PSS reviews, covering a period from 2006 to 2018.

\subsection{Publications' descriptive analysis and synthesis}

The characteristics of the selected publications, such as the main thematic, year, and the outlet (journal) were verified. The impact factor of each journal and the number of citations of each publication were also checked, providing a profile of the selected publications. In addition, general information about PSS addressed by the literature reviews was shown, such as PSS definition, classification, and examples.

In the subsequent step, a coding system was developed for the systematization of the benefits and barriers of PSS addressed by the publications. Content analysis, using the conventional coding technique
[23] was used to codify data collected in the chosen articles. The codes were developed as the content analysis was being conducted. At least three full readings of each publication were necessary to develop the coding criteria. After the first reading that provides the inclusion/exclusion, a second reading was done, in which the most important topics were highlighted in each publication. Later on, a third reading was done to conduct the content analysis and classify the content of the publications according to the coding criteria. During the content analysis, some coding was grouped or changed, and therefore, additional readings were necessary. PSS benefits and barriers identified were grouped in internal (design, economic, and operational) and external ones (customer and context-related). The context-related benefits and barriers were also divided into environmental and social.

\section{Description of selected publications}

Table 1 shows a synthesis of the main information regarding the selected literature reviews on PSS. Those reviews covered a period from 2006 to 2018 , with a considerable number of publications in recent years (more than half of publications selected for analysis were from 2015 to 2018). The first literature review on PSS was that of Tukker and Tischner [24], that deals with more general aspects of service offerings.

Baines et al. [2] is the literature review with the highest number of citations among all in the three databases. This publication also takes into consideration the 'servitization' term. In the same line, some other literature reviews jointly address other issues related to PSS, such as 'service orientation' [25], and 'circular economy' [3]. Recently, revisions of PSS literature address more specific aspects of PSS - e.g., PSS requirements [4] or focus on PSS in particular sectors - e.g., automotive industry [6,26].

Journal of Cleaner Production is the journal with the highest number (6 publications) of PSS reviews. This may be partly due to special issues, such as the special edition on sustainable PSS in 2015, which includes refs. [3] and [27]. Computers in Industry journal has three literature reviews on PSS, followed by two in the International Journal of Production Research. Nine other journals have one publication each in the selected literature reviews. 
Table 1. Summary of literature reviews analyzed

\begin{tabular}{|c|c|c|c|c|c|c|c|}
\hline \multirow[b]{2}{*}{ Year } & \multirow[b]{2}{*}{ Authors } & \multirow[b]{2}{*}{ Journal } & \multirow[b]{2}{*}{ Main thematic } & \multirow{2}{*}{$\begin{array}{l}2018 \\
\text { Impact } \\
\text { Factor }\end{array}$} & \multicolumn{3}{|c|}{ \# of citations } \\
\hline & & & & & $\begin{array}{l}\text { Google } \\
\text { Scholar }\end{array}$ & Scopus & $|S|$ \\
\hline 2006 & Tukker and Tischner & $\begin{array}{l}\text { Journal of Cleaner } \\
\text { Production }\end{array}$ & $\begin{array}{l}\text { Sustainability and } \\
\text { competitiveness of PSS }\end{array}$ & 6.395 & 969 & 492 & 389 \\
\hline 2007 & Baines et al. & $\begin{array}{l}\text { Proceedings of the } \\
\text { Institution of } \\
\text { Mechanical Engineers, } \\
\text { Part B: Journal of } \\
\text { Engineering } \\
\text { Manufacture }\end{array}$ & $\begin{array}{l}\text { State-of-the-art in PSS: concept, } \\
\text { origin and features, examples, } \\
\text { benefits, barriers, tools and } \\
\text { methodologies, and research } \\
\text { challenges }\end{array}$ & 1.752 & 2114 & 1077 & 770 \\
\hline 2009 & Sakao et al. & $\begin{array}{l}\text { Journal of } \\
\text { Manufacturing } \\
\text { Technology Management }\end{array}$ & $\begin{array}{l}\text { Service orientation of manufac- } \\
\text { turers through PSS }\end{array}$ & 2.642 & 136 & 66 & n.a. \\
\hline 2011 & Velamuri et al. & $\begin{array}{l}\text { Journal für } \\
\text { Betriebswirtschaft }\end{array}$ & Hybrid value creation & n.a. & 112 & 54 & n.a. \\
\hline 2011 & Wang et al. & $\begin{array}{l}\text { International Journal of } \\
\text { Production Research }\end{array}$ & PSS lifecycle management & 3.199 & 109 & 71 & 73 \\
\hline 2012 & Cavalieri and Pezzott & Computers in Industry & $\begin{array}{l}\text { State of the art and research } \\
\text { challenges }\end{array}$ & 4.769 & 358 & 240 & 174 \\
\hline 2012 & Vasantha et al. & $\begin{array}{l}\text { Journal of Engineering } \\
\text { Design }\end{array}$ & PSS design methodologies & 1.394 & 323 & 214 & 159 \\
\hline 2013 & Beuren et al. & $\begin{array}{l}\text { Journal of Cleaner } \\
\text { Production }\end{array}$ & $\begin{array}{l}\text { Updated state-of-the-art in PSS: } \\
\text { features, examples, benefits, } \\
\text { drawbacks, and research per- } \\
\text { spectives }\end{array}$ & 6.395 & 486 & 285 & 241 \\
\hline 2013 & Boehm and Thomas & $\begin{array}{l}\text { Journal of Cleaner } \\
\text { Production }\end{array}$ & $\begin{array}{l}\text { PSS in Information Systems, } \\
\text { Business Management, and } \\
\text { Engineering Design }\end{array}$ & 6.395 & 238 & 130 & 98 \\
\hline 2013 & Lightfoot et al. & $\begin{array}{l}\text { International Journal of } \\
\text { Operations and } \\
\text { Production Management }\end{array}$ & Servitization of manufacturing & 4.111 & 314 & 168 & 131 \\
\hline 2015 & Reim et al. & $\begin{array}{l}\text { Journal of Cleaner } \\
\text { Production }\end{array}$ & PSS business models and tactics & 6.395 & 473 & 271 & 220 \\
\hline 2015 & Tukker & $\begin{array}{l}\text { Journal of Cleaner } \\
\text { Production }\end{array}$ & $\begin{array}{l}\text { PSS for resource efficiency and } \\
\text { circular economy }\end{array}$ & 6.395 & 902 & 500 & 415 \\
\hline 2015 & Vasantha et al. & $\begin{array}{l}\text { Journal of the Indian } \\
\text { Institute of Science }\end{array}$ & Advances in designing PSS & 0.742 & 26 & 14 & 10 \\
\hline 2016 & Annarelli et al. & $\begin{array}{l}\text { Journal of Cleaner } \\
\text { Production }\end{array}$ & PSS conceptual framework & 6.395 & 143 & 86 & 66 \\
\hline 2016 & Qu et al. & Computers in Industry & $\begin{array}{l}\text { Design, evaluation and operation } \\
\text { methodologies in PSS }\end{array}$ & 4.769 & 112 & 88 & 65 \\
\hline 2017 & Mahut et al. & $\begin{array}{l}\text { International Journal of } \\
\text { Production Research }\end{array}$ & $\begin{array}{l}\text { PSS for the servitization of the } \\
\text { automotive industry }\end{array}$ & 3.199 & 43 & 24 & 18 \\
\hline 2017 & Sabbagh et al. & $\begin{array}{l}\text { Total Quality } \\
\text { Management \& Business } \\
\text { Excellence }\end{array}$ & $\begin{array}{l}\text { Methodology implications in } \\
\text { automotive PSS }\end{array}$ & 2.181 & 9 & 4 & 5 \\
\hline 2017 & Song & Computers in Industry & $\begin{array}{l}\text { Requirement management for } \\
\text { PSS }\end{array}$ & 4.769 & 57 & 41 & 30 \\
\hline 2018 & $\begin{array}{l}\text { Brambila-Macias } \\
\text { et al. }\end{array}$ & Design Science & $\begin{array}{l}\text { Engineering design and market- } \\
\text { ing in PSS design }\end{array}$ & n.a. & 8 & 6 & 4 \\
\hline 2018 & Lee et al. & Sustainability & PSS BM to value creation & 2.592 & 6 & 2 & 0 \\
\hline
\end{tabular}

Note: The number of citations was referring to February 2020; Google Scholar citation is only for reference purpose; n.a.- not available. 


\section{Results and discussion of content analysis}

\subsection{PSS concept, classification, and general characteristics}

Regarding the definition of PSS in the review papers (refs. $[2,3,6,15,28-30]$ ) the most cited is that of Goedkoop et al. [1], even though it is not a journal source. The previously cited authors defined PSS as "a marketable set of products and services capable of jointly fulfilling a user's need" ([1], p.18), a rather general definition compatible with the time of publication. Another important contribution (cited by refs. [6,10,22,25]) is that of Mont [31], that points out that PSS is a system of products, services, support networks and infrastructure. Baines et al. [2] contribute by presenting the concept of customer value generation through the PSS (also cited by $[6,15,29,32,33]$ ).

The classification of PSS in typologies described by most of the literature reviews is that of Tukker [34], and type comparisons are presented in some publications (e.g., [27,29]). According to Tukker's classification [34], PSS can be dived in three categories: (i) product-oriented; (ii) use-oriented; and (iii) result-oriented. Only two of the analyzed literature reviews [6,20] mention that there are other ways of classifying PSS according to the typology, but they do not describe them.

Some authors (e.g., [2,20] present examples of successful PSS accompanied by the description of the PSS. Table 2 presents the examples highlighted by recent literature reviews. However, few new examples have been included in the most recent reviews. The instances pointed out by the most significant amount of publications analyzed are Xerox and Rolls
Royce. It is worth noticing that examples of PSS are more consolidated in the B2B market. Some literature reviews also show examples of PSS (e.g., case studies) analyzed by empirical articles [15,27]. Nevertheless, the examples highlighted by the cited authors show only publications up to 2011. Mahut et al. [6] highlight the examples studied by industrial sectors (e.g., aeronautics, energy, consumer goods, etc.).

Baines et al. [2] pointed out that regarding origin, most publications were from Scandinavian countries (especially from Sweden), the Netherlands, and Italy, in the period from 1999 to 2006. Some articles on PSS emerged from Asia, and there were no authors from North America directly publishing on the PSS subject. In the previous years before 2007, this paper evidenced that more articles originated in the United Kingdom, also in accordance with Tukker [3]. Velamuri et al. [35] argue that, from 1995 to 2010, most of the research on hybrid value creation originates in OECD countries.

Tukker [3] points out that most of PSS publications are from UK, China, Germany, Sweden, USA, and South Korea (until December 2012). Cranfield University - which adopted PSS as one of its main theoretical concepts - is the main contributor to the PSS research in recent years in the UK. In Asia, the highlight is Seoul National University and Shanghai Jaiotong University. Linköping University and Lund University strongly represent Sweden. Those results differ from the reality pointed out some years ago by Baines et al. [2]. Nevertheless, none of the more recent literature reviews analyses the origin of researches.

Velamuri et al. [35] point out that qualitative research is the dominant research approached. Most of the selected research $(n=265)$ by Boehm and Thomas [10] up to 2012 was of conceptual charac-

Table 2. Examples of successful PSS in recent literature reviews (2016-2018)

\begin{tabular}{|c|c|c|}
\hline Examples & Description & References \\
\hline Ricoh & $\begin{array}{l}\text { Printers and photocopiers provided by a package } \\
\text { called 'pay per page green' that installs, maintains } \\
\text { and collects at the end of its life and the customer } \\
\text { pays only for pages and copies delivered }\end{array}$ & [9] \\
\hline Rolls Royce & $\begin{array}{l}\text { Aircraft turbines - Deli ers a 'power-by-the-hour' } \\
\text { package instead of transferring ownership of tur- } \\
\text { bine engines to airlines }\end{array}$ & [6] \\
\hline Toyota Industries & $\begin{array}{l}\text { It offers materials handling ope ations, such as the } \\
\text { rental of forklifts, whe e the customer pays for their } \\
\text { use, while the company takes care of maintenance, } \\
\text { updating or remanufacturing and eventual disposal }\end{array}$ & [9] \\
\hline Xerox & $\begin{array}{l}\text { Fixed price collection per copy and processes de- } \\
\text { signed for remanufacturing }\end{array}$ & [6] \\
\hline
\end{tabular}


ter. Annarelli et al. [29] argue that most of the selected publications $(n=224)$ concern the construction of theory $(57.6 \%)$ and exploration $(24.1 \%)$, followed by theory refinement research $(11.1 \%)$, and the minority corresponds to the descriptive $(5.8 \%)$ and theory test $(1.3 \%)$. PSS is a relatively new phenomenon, so, qualitative research approach allows having a more in-depth view of the phenomenon under study considering specific factors of the context, patterns, and casual relationships. However, this rich qualitative data needs to be complemented by quantitative studies to improve understanding further. On the other hand, Sabbagh et al. [26], which analyzed publications in the context of the automotive industry, points out that of the selected publications $68 \%$ are quantitative, $25 \%$ are qualitative, and $7 \%$ are mixed.

\subsection{PSS benefits}

Using content analysis, this study identified 16 internal and 20 external PSS benefits. Figure 2 shows the benefits of PSS identified in the PSS literature reviews.

Many publications that highlight the benefits of PSS consider the internal side of organizations, especially the economic ones. Mahut et al. [6] and
Annarelli et al. [29] were the ones that cited more internal benefits of PSS. The most cited internal benefit is differentiation against competitors because services are more difficult to be copied by the competitor. Most of them consider economic advantages that PSS could generate (e.g., 'increase in profit margin'). None benefit that fits into the operational category was found in literature. Possibly, this lack of data is because there are little longitudinal studies about PSS.

Beuren et al. [05] is the literature review that highlights more external PSS benefits. However, few benefits to customers were pointed out. The most cited was 'disconnection from the responsibilities of ownership’. As already identified by Tukker [3], there is still a lack of emphasis on the factors that can foster the acceptance and opportunities to explore the sustainability of the PSS. Moreover, another relevant issue may be the need to learn about PSS customers and monitor their requirements using co-design [36]. Furthermore, in constant expanding markets, understand customer behaviour and experience is a challenge for organizations [37]. One of the current possibilities is associated to digitalized PSS, that aims to integrate products, services, and digital architectures to provide highly customized and customer-oriented

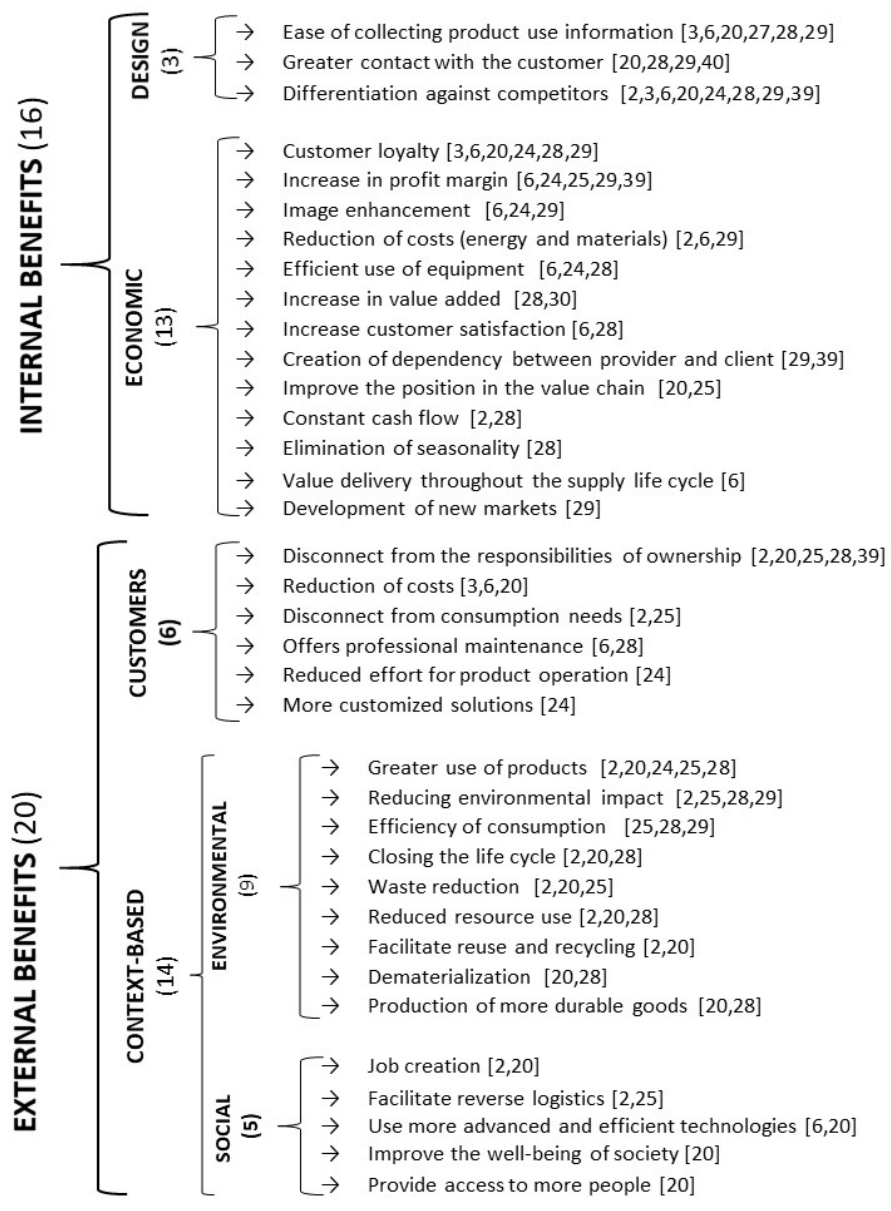

Figure 2. Main benefits off ed by PSS 
solutions [10].

Considering environmental issues, PSS benefits include 'reducing environmental impact' and 'greater use of products'. The environmental benefits can favor both providers and society in general. Annarelli et al. [29] point out that the most recognized benefit (62\% of the publications analyzed by the authors) is the 'reduction of environmental impact', in general. Although it is evident in the literature the economic and environmental benefits, researchers need to identify ways of communicating them clearly to organizations [25]. Conversely, social benefits were rarely addressed by PSS literature reviews and those included 'job creation' and 'facilitate reverse logistics'. Some examples of PSS aligned with social objectives are: Mobisol, that provides electricity services to isolated rural households in East Africa based on a photovoltaic system and software, and Soil, which offers affordable sanitation services with bathroom toilets in Haiti [38].

\subsection{PSS barriers}

The barriers to adopt PSS are positioned on the side of both consumers and providers [2]. Figure 3 depicts the identified PSS barriers organized in cat- egories. Sixteen internals and eight externals barriers were identified. The literature suggests several reasons why PSS have not yet been widely implemented, particularly in the $\mathrm{B} 2 \mathrm{C}$ context, as emphasized by Tukker [3]. Annarelli et al. [29] is the literature review that identified more PSS barriers, that were pointed by $16.5 \%$ of the publications selected by the authors $(n=224)$.

One of the most prominent internal barriers identified in literature was 'resistance to change by stakeholders'. Most of them are related to operational challenges (e.g., 'difficulty in maintaining the system' and 'difficulty in performing reverse logistics'). The economic ones are viewed as critical (e.g., 'need for high initial investment'). Costs of PSS can be high when compared to the production of only one product, which includes labor and transaction costs, since a PSS is usually delivered by a group of companies, resulting in hiring and more complicated revenue-sharing schemes [3]. These barriers identified concerns the difficulties of introducing PSS into organizations.

The high number of PSS internal barriers was in accordance with what literature depicts, i.e. that organizations are facing difficulties in designing and delivering PSS. Thus, it is necessary to investigate the

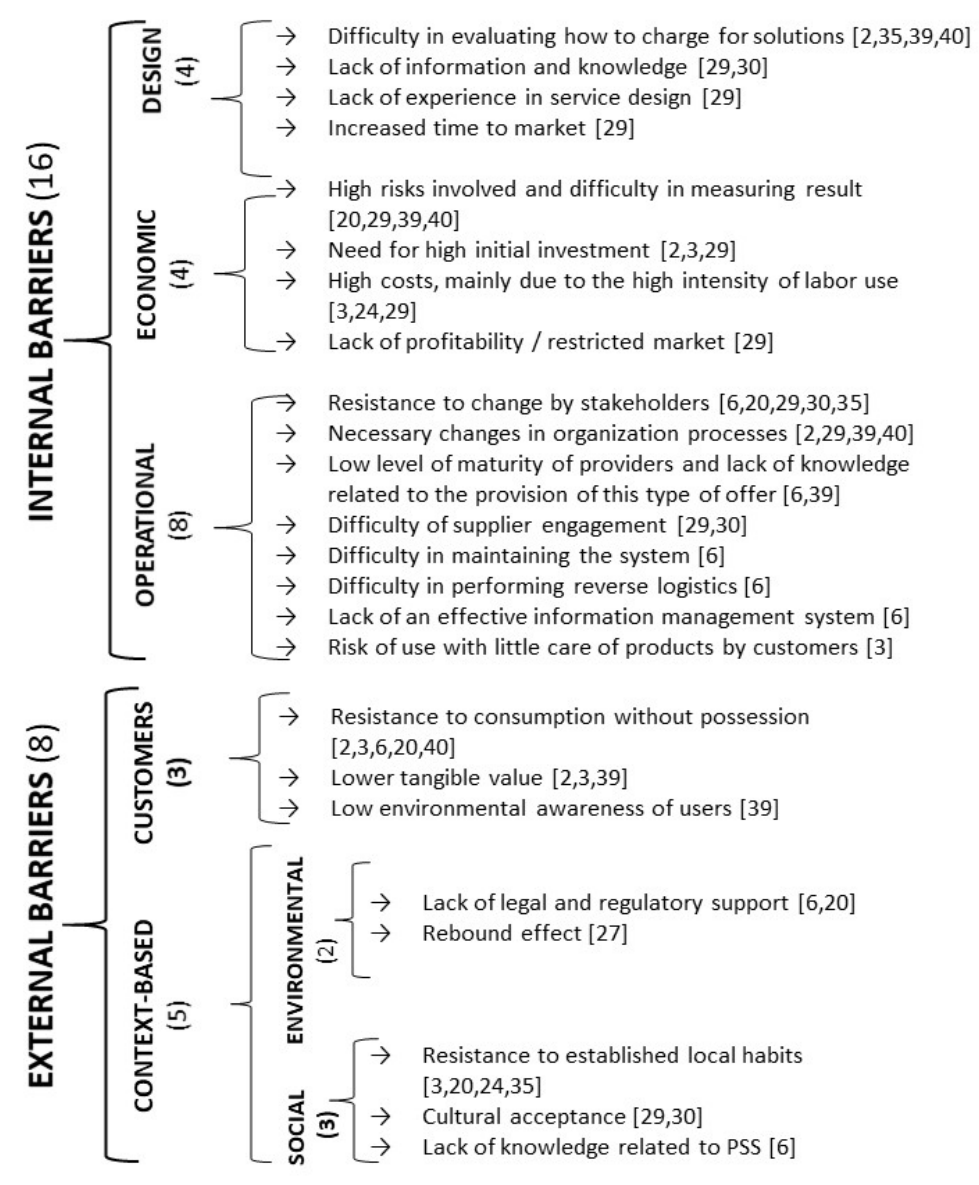

Figure 3. Main PSS barriers 
aspects related to the context that the PSS is implemented to verify if these barriers can be influential for PSS implementation. The use of digital technology may represent challenges to organizations [11]. Nevertheless, those aspects related to new technologies usage were not pointed out as barriers in the analyzed reviews.

External barriers related to customer acceptance include 'resistance to consumption without possession' and 'lower tangible value', while the most cited context-related barrier considers 'resistance to established local habits'. It is recognized that there is a need for cultural change for both providers and customers, expressed by firms' resistance to change and customer acceptance [29]. At the heart of the relationship between providers and customers is the need for mutual trust, which is more evident in the case of long-term contracts [39]. On the customers' side, the main barriers are more apparent in $\mathrm{B} 2 \mathrm{C}$ cases [6].

PSS literature reviews did not address legislations' barriers. Although existing, they are directly involved with the context in which the PSS is implemented. Therefore, there is a need to investigate the aspects related to the context that the PSS is applied to verify if these barriers can be associated to PSS implementation.

\section{Future PSS research opportunities}

A stronger focus on PSS internal benefits is needed to stimulate PSS adoption by organizations. Operational benefits (e.g., PSS simulation, changes in delivery system, and reverse logistics) of PSS represent a gap in PSS literature reviews. Therefore, longitudinal studies could focus on analyzing these aspects.

Benefits for the customers and emphasizing social aspects that PSS could bring about are also missing in literature. PSS examples aligned with social objectives could be better explored, highlighting their social benefits.

Regarding PSS barriers, a research opportunity is to conduct a narrow literature review focusing on PSS barriers, and opportunities to address them, aiming at helping organizations to successfully implement their PSS business models. Understanding customer acceptance barriers and PSS benefits that customers are willing to receive could also help PSS design and implementation. Critical research challenges, such as customer experience and behavior [37] could also be explored linked with PSS customer benefits and barriers.
Analyzing contextual barriers and differences between the places where PSS has been implemented could also be helpful to favor PSS understanding. Other opportunities lie in analyzing the relation between the categories of barriers, for instance, how customers' barriers can influence internal obstacles that organizations are facing.

Smart components integrating artificial intelligence may impact on the PSS solution success [12]. Therefore, studies that deal with how PSS smartness can help to overcome PSS barriers could be fruitful. PSS benefits and barriers related to digitalized PSS and digital services could also be explored. As already mentioned by Lerch and Gotsch [10], further understanding of the digitalized PSS challenges and opportunities is needed, both on theoretical and empirical terms to steer organizations in PSS design and implementation. In the same line, the essential role of predictive analytics was highlighted by Ardolino et al. [14] and could help overcoming PSS operational barriers (e.g. maintenance), which could be explored.

\subsection{Aspects not covered by PSS literature reviews}

Many literature reviews have been conducted in PSS research. Analyzing the aspects covered by PSS literature reviews, especially the most recent ones, it is possible to consolidate previous research and, more important yet, to uncover research opportunities that have not been addressed by the PSS authors, such as:

- A wider analysis of publications using more than one database for search, grouping the publications by area, year, authorship, countries, and thematic. For instance, none of the more recent literature reviews shows which countries currently have the most publications (2013 onwards);

- Classification of publications according to the research methodology approach by areas, highlighting future research opportunities in each one;

- Classification of terminologies used, according to temporal evolution, variations between journal coverage, research groups and countries;

- A broader description of PSS typologies, including the comparison among them;

- A recent list of PSS examples analyzed by the recent literature aiming to guide 
researchers interested in PSS topic to direct their studies;

- Highlights about PSS benefits to customers, including how organizations could develop their PSS value propositions, focusing on the solution of problems suffered by customers using traditional product-oriented business models;

- A literature review focusing on PSS barriers and opportunities to address them aiming to help organizations to implement their PSS business models more effectively;

- Cross-country analysis of PSS benefits and barriers, to identify patterns and differences regarding PSS implementation;

- $\quad$ PSS recent trends and new topics related to PSS that were emerging, such as digitalized PSS, digital services, and smart PSS;

The aspects that were not covered could offer opportunities to enrich PSS field and contribute to a piece of broader knowledge about the subject.

\section{Conclusion}

This paper provided an overview of PSS reviews, identifying their general characteristics, as well as PSS benefits and barriers. Although literature reviews point out more PSS benefits than barriers, the high number of PSS internal barriers is in accordance with what literature shows: organizations are facing difficulties in designing and delivering PSS. Therefore, understanding customer acceptance barriers and also PSS benefits that customers are willing to receive emerge as future research opportunities which can enhance the design and implementation of a PSS. The literature review analysis also allows verifying research streams and some research gaps in PSS literature reviews. For instance, contextual barriers and differences between the places where PSS has been implemented were not explored by PSS reviews and can provide guides to foster successful deployments, and furthermore can be linked to potential social benefits.

As limitations of this work, the content analysis, and the classification of PSS benefits and barriers only covered the authors' knowledge and point of view about the subject. To expand the analysis, other keywords could be also used to provide a wider variety of articles, for instance, those related to servitization.
As a practical contribution, this work offers a general view of PSS-related literature reviews, that could help practitioners interested in getting more knowledge on PSS. The set of PSS benefits and barriers were presented in a reduced and compiled way to facilitate their understanding, and could be used as a checklist or for future data collection. Continuing this work, opportunities lie in analyzing other aspects of PSS-related literature reviews, such as PSS terminologies, as well as research trends and gaps.

\section{Funding}

This study was sponsored by the National Council for Scientific and Technological Development $(\mathrm{CNPq})$, by financing a research project [428946/2018-6] and providing a doctorate grant [140460/2016-0].

\section{References}

[1] M.J. Goedkoop, C.T. Van Halen, H.R. Te Riele, and P.J. Rommens, "Product Service Systems, Ecological and Economic Basics," Report for Dutch Ministries of Environment (VROM) and Economic Affairs (EZ), 1999.

[2] T.S. Baines, H. Lightfoot, E. Steve, A. Neely, R. Greenough, J. Peppard, R. Roy, E. Shehab, A. Braganza, A. Tiwari, J. Alcock, J. Angus, M. Bastl, A. Cousens, P. Irving, M. Johnson, J. Kingston, H. Lockett, V. Martinez, P. Michele, D. Tranfield, I. Walton, and H. Wilson, "State-ofthe-art in product-service systems," Proc. Instn Mech Engrs, Part B: J Engineering Manufacture, vol. 221, no. 10, pp. 1543-1552, 2007, doi: 10.1243/09544054JEM858.

[3] A. Tukker, "Product services for a resource-efficient and circular economy-a review," J. Clean. Prod., vol. 97, pp. 76-91, Jun. 2015, doi: 10.1016/j.jclepro.2013.11.049.

[4] W. Song, "Requirement management for product-service systems: Status review and future trends," Comput Ind, vol. 85, pp. 11-22, Feb. 2017, doi: 10.1016/j.comp ind.2016.11.005.

[5] M. Qu, S. Yu, D. Chena, J. Chu, and B. Tian, "State-of-theart of design, evaluation, and operation methodologies in product service systems," Comput. Ind., vol. 77, pp. 1-14, Apr. 2016, doi: 10.1016/j.compind.2015.12.004.

[6] F. Mahut, J. Daaboul, M. Bricogne, and B. Eynard, "Product-Service Systems for servitization of the automotive industry: a literature review," Int. J. Prod. Res., vol. 55, no. 7, pp. 2102-2120, 2017, doi: 10.1080/00207543.2016.1252864.

[7] M.C. Chiu, M.Y. Kuo, and T.C. Kuo, "A systematic methodology to develop business model of a product service system,” Int. J. Ind. Eng. Manag., vol. 22, no. 3, 2015. Available: http://journals.sfu.ca/ijietap/index.php/ijie/ article/view/1322.

[8] F. Ceschin and I. Gaziulusoy, "Evolution of design for sustainability: From product design to design for system innovations and transitions," Design Stud., vol. 47, pp. 118163, Nov. 2016, doi: 10.1016/j.destud.2016.09.002.

[9] S.A. Brambila-Macias, T. Sakao, and C. Kowalkowski, "Bridging the gap between engineering design and marketing: insights for research and practice in product/ser 
vice system design,” Des. Sc., vol. 4, no. 7, 2018, doi: 10.1017/dsj.2018.3.

[10] C. Lerch and M. Gotsch, "Digitalized Product-Service Systems in Manufacturing Firms: A Case Study Analysis," Res. Technol. Manage., vol. 58, no. 5, pp. 45-52 Sep. 2015, doi: 10.5437/08956308X5805357.

[11] U. Marjanovic, S. Rakic, and B. Lalic, "Digital Servitization: The Next "Big Thing" in Manufacturing Industries BT Advances in Production Management Systems. Production Management for the Factory of the Future," F. Ameri, K. E. Stecke, G. von Cieminski, and D. Kiritsis Eds. Cham, Switzerland: Springer International Publishing, 2019, pp. 510-517, doi: 10.1007/978-3-03030000-5_63.

[12] Z. Wang, C. H. Chen, P. Zheng, X. Li, and L. P. Khoo, "A graph-based context-aware requirement elicitation approach in smart product-service systems," Int. J. Prod. Res., pp. 1-17, Dec. 2019, doi:10.1080/00207543.2019.170 2227.

[13] M. Ardolino, M. Rapaccini, N. Saccani, P. Gaiardelli, G. Crespi, and C. Ruggeri, "The role of digital technologies for the service transformation of industrial companies," Int. J. Prod. Res., vol. 56, no. 6, pp. 2116-2132, May 2017, doi: $10.1080 / 00207543.2017 .1324224$.

[14] P. Zheng, T-J. Lin, Chen C-H., and X. Xu, "A systematic design approach for service innovation of smart productservice systems," J. Clean. Prod., vol. 201, pp. 657-667, Nov. 2018. doi: 10.1016/j.jclepro.2018.08.101.

[15] M. Boehm and O. Thomas. "Looking beyond the rim of one's teacup: a multidisciplinary literature review of Product-Service Systems in Information Systems, Business Management, and Engineering \& Design," J. Clean. Prod., vol. 51, pp. 245-260, Jul. 2013, doi: 10.1016/j.jcle pro.2013.01.019.

[16] C.S. Kim, B.H. Bai, P.B. Kim, and K. Chon, "Review of reviews: A systematic analysis of review papers in the hospitality and tourism literature," International J. Hospit. Manag., vol. 70, pp. 49-58, Feb. 2018, doi: 10.1016/j. ijhm.2017.10.023.

[17] A. Booth, A. Sutton, and D. Papaioannou, "Systematic approaches to a successful literature review," Thousand Oaks, CA, USA: Sage Publications Ltd, 2012.

[18] M. Ballard, and P. Montgomery, "Risk of bias in overviews of reviews: a scoping review of methodological guidance and four item checklist," Research Synthesis Methods, vol. 8, no. 1, pp. 92-108, Jan. 2017, doi: 10.1002/jrsm.1229.

[19] M.J. Grant, and A. Booth, "A typology of reviews: an analysis of 14 review types and associated methodologies," Health Info. Libr. J., vol. 26, no. 2, pp. 91-108, Jun. 2009, doi: 10.1111/j.1471-1842.2009.00848.x.

[20] F.H. Beuren, M.G. Ferreira, and P.A. Cauchick Miguel, "Product-service systems: a literature review on integrated products and services,” J. Clean. Prod., vol. 47, pp. 222-231, May 2013, doi: 10.1016/j.jclepro.2012.12.028.

[21] N. Suzić E. Sandrin, S. Suzić, C. Forza, A. Trentin, and Z. Anišić, Z, "Implementation guidelines for mass customization: a researcher-oriented view", Int. J. Ind. Eng. Manag., vol. 4, pp. 229-243, Dec. 2018, doi: 10.24867/IJIEM-2018-4-229.

[22] D. Gough, S. Oliver, and J. Thomas (Ed.), "An introduction to systematic reviews,". Thousand Oaks, CA, USA: Sage Publications Ltd, 2012.

[23] H-F. Hsieh and S.E. Shannon, "Three approaches to qualitative content analysis," Qual. Health. Res., vol. 15, no. 9, pp. 1277-1288, Nov. 2005, doi: $10.1177 / 1049732305276687$.

[24] A. Tukker and U. Tischner, "Product-services as a research field: past, present and future. Reflections from a decade of research,” J. Clean. Prod., vol. 14, no. 17, pp. 1552-1556,
2006, doi: 10.1016/j.jclepro.2006.01.022.

[25] T. Sakao, G.Ö. Sandström, and D. Matzen, "Framing re search for service orientation of manufacturers through PSS approaches,” J. Manuf. Tech. Manag., vol. 20, no. 5, pp. 754-778, 2009, doi: 10.1108/17410380910961082.

[26] O. Sabbagh, M.N. Ab Rahman, W.R. Ismail, and W.M.H. Wan Hussain, "Methodology implications in automotive product-service systems: a systematic literature review," Total Qual. Manag. Bus., vol. 28, no. 13-14, pp. 1632-1668, 2017, doi: 10.1080/14783363.2016.1150169.

[27] W. Reim, V. Parida, and D. Örtqvist, "Product-Service Systems (PSS) business models and tactics-a systematic literature review," J. Clean. Prod., vol. 97, pp. 61-75, Jun. 2015, doi: 10.1016/j.jclepro.2014.07.003.

[28] P.P. Wang, X.G. Ming, D. Li et al. "Status review and research strategies on product-service systems," Int. J. Prod. Res., vol. 49, no. 22, pp. 68636883, Feb. 2011, doi: 10.1080/00207543.2010.535862.[29]

[29]A. Annarelli, C. Battistella, and F. Nonino, "Product service system: A conceptual framework from a systematic re view,". J. Clean. Prod., vol. 139, pp. 1011-1032, Dec. 2016, doi: 10.1016/j.jclepro.2016.08.061.

[30] H. Lee, H. Seo, and Y. Geum, "Uncovering the Topic Landscape of Product-Service System Research: from Sustainability to Value Creation,” Sustainability, vol. 10, no. 4, pp. 911, 2018, doi:10.3390/su10040911.

[31] O. Mont, "Clarifying the concept of product-service system,” J. Clean. Prod., vol.10, no.3, pp.237-24.5, Jun. 2002, doi: 10.1016/S0959-6526(01)00039-7.

[32] G.V.A. Vasantha, R. Roy, A. Lelah, and D. Brissaud, "A review of product-service systems design methodologies," J. Eng. Des., vol. 23, no. 9, pp. 635-659, 2012, doi: 10.1080/09544828.2011.639712.

[33] G.V.A Vasantha, R. Roy,J.R. Corney, “Advances in designing product-service systems," Jl. of IISc., vol. 95, no. 4, pp. 429448, 2015. Available at: http://journal.iisc.ernet.in/index. $\mathrm{php} /$ iisc/article/view/4588/4885..

[34] A. Tukker, "Eight types of product-service system: eight ways to sustainability? Experiences from SusProNet," Bus. Strat. Environ., vol. 13, no. 4, pp. 246-260, 2004, doi: $10.1002 /$ bse.414.

[35] V.K. Velamuri, A.-K. Neyer, and K.M. Möslein, "Hybrid value creation: a systematic review of an evolving research area," J. für Betriebswirtschaft, vol. 61, no. 1, pp. 3-35, Feb. 2011, doi: 10.1007/s11301-011-0070-5.

[36] P.C. Gembarski and R. Lachmayer, "Designing Customer Co-Creation: Business Models and Co-Design Activities," Int. J. Ind. Eng. Manag., vol. 8, no 3, pp. 121-130, Sep. 2017. Available: http://ijiemjournal.uns.ac.rs/v08/v08-03.html.

[37] M. Weber and C. G. Chatzopoulos, "Digital customer experience: the risk of ignoring the non-digital experience", Int. J. Ind. Eng. Manag., vol. 10, no. 3, pp. 201-210, Sep. 2019, doi: 10.24867/IJIEM-2019-3-240.

[38] A. Helkkula, C. Kowalkowski, and B. Tronvoll, "Archetypes of Service Innovation: Implications for Value Cocreation,” J. Serv. Res., vol. 21, no. 3, pp. 284-301, Jan. 2018, doi: 10.1177/1094670517746776.

[39] S. Cavalieri and G. Pezzotta, "Product-Service Systems Engineering: State of the art and research challenges," Comput. Ind., vol. 63, no. 4, pp. 278-288, May 2012, doi: 10.1016/j.compind.2012.02.006.

[40] H. Lightfoot, T. Baines, and P. Smart, "The servitization of manufacturing: A systematic literature review of interdependent trends," Int. J. Oper. Prod. Manag., vol. 33, no. 11/12, pp. 14.08-1434, Nov. 2013, doi: 10.1108/ IJOPM-07-2010-0196. 